\title{
Towards a Strategic Shift? \\ On the Evolution of Poland's Position \\ in the Global Economy in 2003-2012
}

\author{
Marlena Dzikowska \\ Poznań University of Economics and Business, Poland \\ marlena.dzikowska@ue.poznan.pl \\ Marian Gorynia \\ Poznań University of Economics and Business, Poland \\ m.gorynia@ue.poznan.pl \\ Piotr Trạpczyński \\ Poznań University of Economics and Business, Poland \\ piotr.trapczynski@ue.poznan.pl
}

\begin{abstract}
Poland, like other economies of the region of Central and Eastern Europe, embarked upon a process of radical economic transformation since 1989, leading to the introduction of a market-based economy. This process was accompanied and driven by a gradual opening of the economy to different forms of international economic activity, including notably a dynamic growth of foreign trade. The paper provides an analytical account on the increasing internationalisation of the Polish economy, pointing to the existence of a certain paradox. On the one hand, the process of catching up with advanced economies requires higher growth rates in terms of GDP. However, the said internationalisation also makes the economy more dependent on the economic situation in other countries. The analysis also indicates that a strategic shift in sectoral and geographic terms occurred in Polish exports. The paper concludes with recommendations for economic policy.
\end{abstract}

Key Words: internationalisation, foreign direct investment, exports, economic policy, economic transformation

JEL Classification: P27, F 41

https://doi.org/10.26493/1854-6935.15.145-168

\section{Introduction}

One of the most salient features of the dramatic changes occurring in the Polish economy because of the transformation process initiated back in 1990 was its systematic integration into the global economic system. While the centrally planned economy imposed significant restrictions 
both in the area of goods and services flows, and capital mobility, market economy was open for international cooperation. The basic symptoms for this opening were the dynamic changes in the Polish foreign trade and foreign direct investment (FDI) flows. The transformation process led to an explosion of entrepreneurial activity in the long run, including the start of foreign operations by Polish firms. The internationalisation of firms is a phenomenon which is particularly relevant for economic development due to its potential for enhancing demand for goods and services offered by domestic firms and, consequently, for increasing the employment level. This aspect plays a crucial role in small and/or mature economies with a relatively low potential for domestic market growth. The high dynamics of export may therefore serve as an indicator of enhanced competitiveness of an economy and of the firms' ability to fulfil foreign markets requirements (Gorynia and Kowalski 2008). Poland is an open and - in the case of most industries - a relatively mature market in which successful long-term firm operations require facing the rivalry from both domestic and international players. The progressing liberalisation of the flows of goods and services and the related increase of competition in the domestic market significantly afflicts development perspectives for firms that decide to confine their operations merely to the local market, for even such behaviour does not necessarily allow avoiding confrontation with foreign competitors. Thus, in many cases internationalisation poses a unique chance for improving competitiveness and becomes an inherent constituent of the strategy of Polish firms towards the expansion of foreign investors (Gorynia 2005; Gorynia et al. 2013).

Exports, imports and FDI are common modes of internationalisation amongst Polish firms, whereby the latter are still implemented relatively seldom in spite of a visible increase of interest in this expansion strategy in the recent years. Given the volume constraints of the present paper, as well as the impact of the said internationalisation modes on the economy, the main emphasis of further analysis will be placed upon international trade, including particularly export activity of firms located in Poland in the period between 2006 and 2012.

The present paper is based on the analysis of the changes, which occurred in the position of Poland's economy as opposed to the world and the European Union, in specific. The objective of this analysis is to seize relationships, which appeared in the investigated period. The paper also undertakes an attempt at verifying the information about a geographic and sectoral re-orientation of Polish exports, which started to appear in 
publications at the beginning of 2014 (see e.g. Kowalczyk 2014; Kozłowski 2014; Siemiończyk 2014).

\section{Export Reorientation: A Literature Review}

As Central and Eastern European countries have been undergoing significant political and economic transformations, researchers have paid some attention to changes happening in the geographic structure of their exports (see i.e.: Lendesmann and Szekely 1995; Kamiński 1996; Kamiński, Wang and Winters 1996; Brenton and Gros 1997; Winiecki 2000a; Djankov and Freund 2002; Kandogan 2006). Such studies had been especially popular during the last decade of the 2oth century, due to the necessary reorientation of Central and Eastern European countries' exports and the need to change their previous trade partners originating from the Council for Mutual Economic Assistance to those coming from market economies in general and neighbouring European Union countries in particular. It is often highlighted that these changes were, on the one hand, partially natural due to the geographic proximity of the mentioned countries and earlier industrial cooperation among them and, on the other hand, they were administratively facilitated by state treaties called association agreements. At the same time, the scope and speed of the fundamental economic changes that the $\mathrm{CEE}$ countries experienced were unprecedented.

The studies of the dramatic and fundamental reorientation of the CEE countries' exports can be divided into two groups. The first group is focused on the analyses of the mentioned phenomenon by the use of the gravity models (see Lendesmann and Szekely 1995; Kamiński 1996; Brenton and Gros 1997; Winiecki 2000a; Djankov and Freund 2002; Kandogan 2006). In particular, those studies tried to assess the export potential of the CEE countries to market economies, by taking into consideration for example: transportation costs, demand and supply conditions, GDP of partner countries, common language, etc. While doing so, researchers tried to answer if the export reorientation of the CEE countries was complete or not. The second group applied more descriptive approach (see Vanyai and Viszt 1992; Kamiński, Wang, and Winters 1996; Szalavetz and Lucke 1999; Hoekman and Djankov 1999; Winiecki 200ob) and tried to relate export reorientation to other aspects of $\mathrm{CEE}$ countries' functioning, as for example social and political changes, welfare state development, global re-integration etc.

Before focusing directly on the analysis of the more up-to-date export 
position of Poland it may be useful to highlight the importance of involvement of CEE countries in general, and Poland in particular, into the trade with other market economies. First of all, all the member countries of the Council for Mutual Economic Assistance experienced severe decrease in foreign trade after the collapse of Soviet Union. This means, that the countries that were at that time extremely troubled with internal changes of political, social and economic nature, were additionally hit by a decrease in the external demand of their products. At least in the case of Poland, the market was unsaturated and ready to pull the extra amount of goods, however even this did not prevent it from massive bankruptcies of public companies, dramatic rise in unemployment rate, and as a result, relatively slower growth of GDP. The rapid trade reorientation and recovery played an important role as a driver of further economic growth. Secondly, the goods exported by transition economies at the beginning of the goties were very often of poor quality. The reorientation of export towards the market economies enforced qualitative changes in the commodity structure of exports. This required wider changes in terms of increasing the value-added content of products through $\mathrm{R} \& \mathrm{D}$ and capitalintensive technologies, privatisation and integration of businesses with global markets and giving more priority to more profitable exports. All those changes were important for securing a sustainable path of growth. Thirdly, the character of foreign trade has been changing from the interindustry trade into the intra-industry trade, which allowed participation of firms originating from CEE countries in the global supply chains.

\section{Analysis of the Polish Case \\ THE OVERALL CONTEXT OF FOREIGN TRADE REFORMS IN POLAND}

During Poland's transformation process in the 1990s and 200os, the country undertook different attempts at integrating itself into the global economy (Gorynia, Nowak, and Wolniak 2007). By increasing the linkages with the world economy, Poland aimed at fostering growth and closing the income gap to advanced economies of Western Europe. Up to the outset of economic changes in the CEE region in the 1990s, Poland had remained largely closed towards its external environment (Gorynia et al. 2014b). Hence, international business operations were not used for stimulating the economy, enhancing domestic productivity or exploiting the international allocation of labour. Interestingly, the structure of foreign 
trade was distorted, since exports from Poland predominantly focused upon the member states of the Council for Mutual Economic Assistance (CMEA), while exports to countries of the Organisation for Economic Co-Operation and Development (OECD) were significantly lower than the it could be expected based on the overall economic performance of the country (Gorynia 2002b).

Accordingly, after the beginning of the transformation process, the government was confronted with the challenge of enabling the advantages of globalisation by fostering reforms and growth (Gorynia et al. 2014b). It thus liberalised prices and market regimes, privatised most state-owned enterprises, redirected the country's trade from the former CMEA trading bloc towards the European Union, and opened up most of its industries to foreign direct investment (Ali, Nowak, and Pöschl 2001; Gorynia and Wolniak 2002). These integration processes intensified the interdependences of Poland with other countries and thus bringing a number of positive effects. In general, the increased participation in international trade and international investment supported the country in modernizing and restructuring its economy. The implementation of a more open foreign economic policy in most CEE countries at first (1990-1991) relied on the liberalisation of commodity prices, increase in subsidies, devaluation of Polish currency and introduction of its external convertibility, as well as significant import liberalisation (Gorynia 2002a). Subsequently, from early 1990 to August 1991, the liberalisation of commodity prices, increases in subsidies, devaluation of Polish currency and introduction of its external convertibility ensued, accompanied by significant import liberalisation. Further, from September 1991 to late 1993, adjustments within the process of gradual association with the European Union and the Central European Free Trade Area (CEFTA) led to further liberalisation in international trade. In specific, duties and customs quotas on raw materials were suspended. In addition, the transition agreement with the EU assumed the establishment of free trade zones for industrial goods. This led to a more active trade policy, restructuring of production and exports at the beginning of 1994, when the European Agreement defining the principles of Poland's association with the EU was implemented. One of the attempts at stimulating inflows of foreign direct investment was the introduction of investment incentives, including a partial deduction of investment outlays from taxable income. The years 1995-1998 brought about further liberalisation of goods import (resolutions of the Final Act of the Uruguay Round, European Agreement, agree- 
ments with CEFTA and the European Free Trade Association), as well as a removal of compulsory reselling of hard currency to banks by exporters, liberalisation of capital outflows from Poland. It was at that time that first export supporting instruments (export credits and insurance of export credits) were being introduced, albeit at a limited scope.

These initial changes in foreign trade policy were further accelerated by Poland's accession to international organisations such as the OECD (1996) and the EU (2004). However, for the exporters, the elimination of a centralised regulation of trade immediately removed a source of subsidies and imposed the responsibility of securing self-financing (Gorynia et al. 2014b). At the same time, the dissolution of the CMEA in 1991 had the effect of stimulating the internationalisation of existing and newly established firms to new geographic markets, while a network of business ties established in the previous economic system could still be leveraged.

EVOLUTION OF THE POSITION OF POLAND'S ECONOMY

IN THE WORLD AND IN THE EUROPEAN UNION

In order to analyse the effects of the transition process, and specifically the evolution of foreign trade policy, on the internationalisation of the Polish economy, the evolution of international trade deserves particular attention. ${ }^{1}$ Its dynamic development has generated numerous advantages for the Polish economy. At the same time, however, it poses certain threats, which may potentially reduce the advantages arising from an open economy.

The analysis of GDP data relied on UNCTAD data for the period under study, including both absolute and per capita values. All figures were calculated according to official exchange rates. The analysis of dynamics required computing change indices, both year-to-year and with reference to year 2003 as the last year before Poland's accession to the European Union. In all cases, Poland was compared to both the European Union and the global economy. As far as Poland's exports are concerned, apart from the aforementioned indicators, the share of exports of goods and services in GDP value was calculated. Moreover, the Export Performance Index was calculated based on annual values of goods export. Finally, in order to account for the changes in the profile of Polish exports, detailed data from the Central Statistical Office of Poland (https://stat.gov.pl) were used to compute:

- the shares of the Eurozone and European Union in Poland's total export of goods in the years 2006-2012, 
- the dynamics of Poland's export to the Eurozone and the European Union in the years 2006-2012 (year to year), and

- the shares in Poland's total export of goods and dynamics of Poland's export to the largest foreign trade partners in 2006-2012.

The data included in table 1 suggest that in the period 2003-2012 the GDP of Poland expressed in current prices increased more than twofold (by $225.9 \%$ ), whilst in the case of global GDP the growth rate amounted to $189.7 \%$. For the EU 27 this indicator attained a level of $145.3 \%$. In the case of Poland, this variable was twice (in 2009 and 2012) lower than 100\% yearto-year, while in relation to the global economy the level of this indicator below $100 \%$ was observed only in one year (in 2009). For the EU 27, this same indicator was lower than 100\% in the years 2009, 2010, and 2012.

In regards to GDP per capita evolution, Poland experienced a similar growth rate for the period 2003-2012 as that of the entire GDP (224.2\%). In the same period, the growth indicator of the global GDP per capita was $170.3 \%$. For EU 27 countries, this indicator amounted to $140.5 \%$. In yearto-year terms, the value of this indicator for Poland was lower than $100 \%$ twice (in 2009 and 2012). For the world, the value of this indicator in yearto-year terms was lower than $100 \%$ only in 2009. In the EU 27 countries, such situation occurred in 2009, 2010, and 2011.

In the investigated period, Poland occupied the highest position globally in 2008 , which was 18 th. The lowest 18 th position was held in 20032005. As regards Poland's position in the E U27, Poland moved from the 10th position in 2003-2005 to 8th position in 2012. In 2008 Poland scored 7 th in the same ranking, which was its highest result ever. In regards to the evolution of GDP per capita, Poland was on the 68th position in the world in 2003 and moved to 59th position in 2012. Poland's position in the $\mathrm{EU} 27$ was very stable and remained at the level of $23-25$ throughout the entire investigated period.

As far as the so-called active internationalisation of the Polish economy vis-a-vis the economies of the world and of EU 27 is concerned, only export will be analysed here. Comparative data referring to the exports of Poland, world and EU 27 are included in table $3 .{ }^{2}$ In the years 20032012, the indicator of export growth for Poland amounted to $306.7 \%$, for the world $-243.1 \%$, and for the EU $27-184.7 \%$. For Poland, the export value indicator in year-to-year terms achieved a value higher than $100 \%$ at two occasions (in 2009 and 2012). Such situation for the world exports occurred only once in 2009, and twice for the EU 27 (2009 and 2012). As 
TABLE 1 GDP in the period 2003-2012 (current prices and exchange rates)

\begin{tabular}{|c|c|c|c|c|c|c|c|}
\hline Year & Region & $(1)$ & $(2)$ & (3) & (4) & $(5)$ & (6) \\
\hline \multirow[t]{4}{*}{2003} & Poland & 216801 & 100.0 & - & 5676 & 100.0 & - \\
\hline & EU 25 & 10811815 & 100.0 & 100.0 & 28129 & 100.0 & - \\
\hline & EU 27 & 11407970 & 100.0 & 100.0 & 23361 & 100.0 & 100.0 \\
\hline & World & 37654430 & 100.0 & - & 5949 & 100.0 & - \\
\hline \multirow[t]{4}{*}{2004} & Poland & 252769 & 116.6 & 116.6 & 6621 & 116.7 & 116.7 \\
\hline & EU 25 & 13070342 & 120.9 & 120.9 & 28365 & 100.8 & 100.8 \\
\hline & EU 27 & 13171420 & 115.5 & 115.5 & 26857 & 115.0 & 115.0 \\
\hline & World & 42371251 & 112.5 & 112.5 & 6614 & 111.2 & 111.2 \\
\hline \multirow[t]{4}{*}{2005} & Poland & 303912 & 140.2 & 120.2 & 7963 & 140.3 & 120.3 \\
\hline & EU 25 & 13643917 & 126.2 & 104.4 & 29467 & 104.8 & 103.9 \\
\hline & EU 27 & 13771984 & 120.7 & 104.6 & 27962 & 119.7 & 104.1 \\
\hline & World & 45849262 & 121.8 & 108.2 & 7073 & 118.9 & 106.9 \\
\hline \multirow[t]{4}{*}{2006} & Poland & 341597 & 157.6 & 112.4 & 8949 & 157.7 & 112.4 \\
\hline & EU 25 & 14527715 & 134.4 & 106.5 & 31227 & 111.0 & 106.0 \\
\hline & EU 27 & 14683621 & 128.7 & 106.6 & 29686 & 127.1 & 106.2 \\
\hline & World & 49698900 & 132.0 & 108.4 & 7576 & 127.4 & 107.1 \\
\hline \multirow[t]{4}{*}{2007} & Poland & 425129 & 196.1 & 124.5 & 11132 & 196.1 & 124.4 \\
\hline & EU 25 & 16985806 & 157.1 & 116.9 & 34195 & 121.6 & 109.5 \\
\hline & E U 27 & 16985806 & 148.9 & 115.7 & 34195 & 146.4 & 115.2 \\
\hline & World & 55996876 & 148.7 & 112.7 & 8437 & 141.8 & 111.4 \\
\hline \multirow[t]{4}{*}{2008} & Poland & 529423 & 244.2 & $124 \cdot 5$ & 13853 & 244.1 & 124.4 \\
\hline & EU 25 & 18271448 & 169.0 & 107.6 & 36634 & 130.2 & 107.1 \\
\hline & EU 27 & 18271448 & 160.2 & 107.6 & 36634 & 156.8 & 107.1 \\
\hline & World & 61380972 & 163.0 & 109.6 & 9141 & 153.7 & 108.3 \\
\hline \multirow[t]{4}{*}{2009} & Poland & 430912 & 198.8 & 81.4 & 11266 & 198.5 & 81.3 \\
\hline & EU 25 & 16334168 & 151.1 & 89.4 & 32626 & 116.0 & 89.1 \\
\hline & EU 27 & 16334168 & 143.2 & 89.4 & 32626 & 139.7 & 89.1 \\
\hline & World & 58193951 & 154.5 & 94.8 & 8567 & 144.0 & 93.7 \\
\hline
\end{tabular}

far as export dynamics of per capita values go, in the investigated period this indicator amounted to $306.0 \%$ for Poland, $219.0 \%$ for the world, and $178.6 \%$ for the EU 27. In year-to-year terms, an indicator lower than $100 \%$ could be observed in 2009 and 2012 for Poland, the world and E U 27 countries. It must be emphasised that significant changes of Poland's share in 
TABLE 1 Continued from the previous page

\begin{tabular}{rlrrrrrr}
\hline Year & Region & $(1)$ & $(2)$ & $(3)$ & $(4)$ & $(5)$ & $(6)$ \\
\hline 2010 & Poland & 469799 & 216.7 & 109.0 & 12274 & 216.3 & 108.9 \\
& EU25 & 16276284 & 150.5 & 99.6 & 32399 & 115.2 & 99.3 \\
& EU 27 & 16276284 & 142.7 & 99.6 & 32399 & 138.7 & 99.3 \\
& World & 63580799 & 168.9 & 109.3 & 9253 & 155.5 & 108.0 \\
\hline \multirow{2}{*}{ O11 } & Poland & 514115 & 237.1 & 109.4 & 13424 & 236.5 & 109.4 \\
& EU25 & 17596476 & 162.8 & 108.1 & 34925 & 124.2 & 107.8 \\
& EU 27 & 17596476 & 154.2 & 108.1 & 34925 & 149.5 & 107.8 \\
& World & 70201920 & 186.4 & 110.4 & 10068 & 169.2 & 108.8 \\
\hline \multirow{2}{2}{2012} & Poland & 489852 & 225.9 & 9453 & 12820 & 225.9 & 95.5 \\
& EU25 & 16573561 & 153.3 & 94.2 & 32812 & 116.6 & 93.9 \\
& EU27 & 16573561 & 145.3 & 94.2 & 32812 & 140.5 & 93.9 \\
& World & 72683234 & 189.7 & 101.8 & 10268 & 170.3 & 100.6 \\
\hline
\end{tabular}

NOTES Column headings are as follows: (1) GDP (milion USD according to official exchange rate), $(2)$ change $(\%, 2003=100),(3)$ change $(\%$, previous year $=100),(4)$ GDP per capita (USD), $(5)$ change $(\%, 2003=100),(6)$ change $(\%$, previous year $=100)$. Calculations based on data from UNCTAD (http://unctadstat.unctad.org).

TABLE 2 Export of Goods (current prices and exchange rates)

\begin{tabular}{rlrrrrrrr}
\hline Year & Region & $(1)$ & $(2)$ & $(3)$ & $(4)$ & $(5)$ & $(6)$ & $(7)$ \\
\hline 2003 & Poland & 61007 & 100.0 & - & 1597 & 100.0 & - & 33.30 \\
& EU 25 & 2775767 & 100.0 & - & 7222 & 100.0 & - & 33.5 \\
& EU 27 & 3006826 & 100.0 & - & 6157 & 100.0 & - & 34.3 \\
& World & 7474601 & 100.0 & 100.0 & 1177 & 100.0 & 100.0 & 24.9 \\
\hline \multirow{2}{2}{2004} & Poland & 81583 & 133.7 & 133.7 & 2137 & 133.8 & 133.8 & 37.55 \\
& EU 25 & 3555623 & 128.1 & 128.1 & 7716 & 106.9 & 106.9 & 35.5 \\
& EU 27 & 3589054 & 119.4 & 119.4 & 7318 & 118.9 & 118.9 & 35.6 \\
& World & 9083607 & 121.5 & 121.5 & 1413 & 120.1 & 120.1 & 26.9 \\
\hline
\end{tabular}

world exports occurred. It increased systematically in the period 20032009, showing annual growth rates from $0.82 \%$ to $1.14 \%$ in six consecutive years, while the most recent three years witnessed a downward trend (decline to $1.03 \%$ in 2012). In regards to the level of Poland's export in relation to EU 27 exports, a clear upward trend can be observed - from $2.03 \%$ in 2003 to $3.37 \%$ in 2012.

The share of goods and services in GDP grew dynamically and system- 
TAB LE 2 Continued from the previous page

\begin{tabular}{|c|c|c|c|c|c|c|c|c|}
\hline Year & Region & (1) & (2) & (3) & (4) & (5) & (6) & (7) \\
\hline \multirow[t]{4}{*}{2005} & Poland & 96514 & 158.2 & 118.3 & 2529 & 158.3 & 118.3 & 37.12 \\
\hline & EU 25 & 3846671 & 138.6 & 108.2 & 8308 & 115.0 & 107.7 & 36.9 \\
\hline & E U 27 & 3886130 & 129.2 & 108.3 & 7890 & 128.1 & 107.8 & 36.9 \\
\hline & World & 10373128 & 138.8 & 114.2 & 1594 & 135.5 & 112.8 & 28.2 \\
\hline \multirow[t]{4}{*}{2006} & Poland & 117238 & 192.2 & 121.5 & 3071 & 192.3 & 121.5 & 40.33 \\
\hline & EU 25 & 4369835 & 157.4 & 113.6 & 9393 & 130.1 & 113.1 & 39.2 \\
\hline & E U 27 & 4417478 & 146.9 & 113.7 & 8931 & 145.0 & 113.2 & 39.2 \\
\hline & World & 11995325 & 160.5 & 115.6 & 1822 & 154.9 & 114.3 & 30.0 \\
\hline \multirow[t]{4}{*}{2007} & Poland & 144739 & 237.2 & 123.5 & 3790 & $237 \cdot 3$ & 123.4 & 40.79 \\
\hline & EU 25 & 5132510 & 184.9 & 117.5 & 10333 & 143.1 & 110.0 & 39.8 \\
\hline & E U 27 & 5132510 & 170.7 & 116.2 & 10333 & 167.8 & 115.7 & 39.8 \\
\hline & World & 13883426 & 185.7 & 115.7 & 2084 & 177.1 & 114.4 & 31.0 \\
\hline \multirow[t]{4}{*}{2008} & Poland & 176321 & 289.0 & 121.8 & 4613 & 288.9 & 121.7 & 39.96 \\
\hline & E U 25 & 5668288 & 204.2 & 110.4 & 11365 & 157.4 & 110.0 & 40.9 \\
\hline & E U 27 & 5668288 & 188.5 & 110.4 & 11365 & 184.6 & 110.0 & 40.9 \\
\hline & World & 15953617 & 213.4 & 114.9 & 2367 & 201.2 & 113.6 & 32.4 \\
\hline \multirow[t]{4}{*}{2009} & Poland & 141078 & 231.2 & 80.0 & 3688 & 230.9 & 79.9 & 39.39 \\
\hline & E U 25 & 4404220 & 158.7 & 77.7 & 8797 & 121.8 & 77.4 & 37.0 \\
\hline & E U 27 & 4404220 & 146.5 & 77.7 & 8797 & 142.9 & 77.4 & 37.0 \\
\hline & World & 12415110 & 166.1 & 77.8 & 1821 & 154.8 & 76.9 & 27.5 \\
\hline \multirow[t]{4}{*}{2010} & Poland & 165599 & 271.4 & 117.4 & 4326 & 270.9 & 117.3 & 42.22 \\
\hline & EU 25 & 4953887 & 178.5 & 112.5 & 9861 & 136.6 & 112.1 & 40.8 \\
\hline & E U 27 & 4953887 & 164.8 & 112.5 & 9861 & 160.2 & 112.1 & 40.8 \\
\hline & World & 15127757 & 202.4 & 121.8 & 2194 & 186.5 & 120.5 & 30.0 \\
\hline
\end{tabular}

atically in Poland - it reached $33.3 \%$ in 2003 , while it was at the level of already $46.2 \%$ in 2012 . For the world, this indicator reached $24.9 \%$ in 2003 and $31.6 \%$ in 2012 . For the EU 27 group of countries, these values were $34.3 \%$ and $44.6 \%$, respectively.

A synthetic measure reflecting the changes of a given country's position in exports are its positions occupied in rankings. In 2003, Poland took the 3 oth position in the world in terms of the value of goods and services, and specifically 32 th in goods export and 34 th in services ex- 
TAB LE 2 Continued from the previous page

\begin{tabular}{rlrrrrrrr}
\hline Year & Region & $(1)$ & $(2)$ & $(3)$ & $(4)$ & $(5)$ & $(6)$ & $(7)$ \\
\hline \multirow{2}{2011}{} & Poland & 193740 & 317.6 & 117.0 & 5059 & 316.7 & 116.9 & 44.99 \\
& EU 25 & 5809377 & 209.3 & 117.3 & 11530 & 159.7 & 116.9 & 43.8 \\
& EU 27 & 5809377 & 193.2 & 117.3 & 11530 & 187.3 & 116.9 & 43.8 \\
& World & 18145522 & 242.8 & 119.9 & 2602 & 221.2 & 118.6 & 32.0 \\
\hline \multirow{2}{2012}{} & Poland & 187238 & 306.9 & 96.6 & 4887 & 306.0 & 96.6 & 46.19 \\
& EU25 & 5553366 & 200.1 & 95.6 & 10994 & 152.2 & 95.4 & 44.6 \\
& EU 27 & 5553366 & 184.7 & 95.6 & 10994 & 178.6 & 95.4 & 44.6 \\
& World & 18170388 & 243.1 & 100.1 & 2577 & 219.0 & 99.0 & 31.7 \\
\hline
\end{tabular}

NOTES Column headings are as follows: (1) GDP (milion USD according to official exchange rate), $(2)$ change $(\%, 2003=100),(3)$ change $(\%$, previous year $=100),(4)$ GDP per capita (USD), (5) change $(\%, 2003=100),(6)$ change $(\%$, previous year $=100),(7)$ share of exports of goods and services in GDP (\%). Calculations based on data from UNCTAD (http://unctadstat.unctad.org).

TABLE 3 Export of Goods in 2003-2012: Poland's Share (current prices and exchange rates)

\begin{tabular}{|c|c|c|c|c|c|c|c|}
\hline (1) & (2) & (3) & (4) & (1) & (2) & (3) & (4) \\
\hline 2003 & 0.82 & 2.20 & 2.03 & 2008 & 1.11 & 3.11 & 3.11 \\
\hline 2004 & 0.90 & 2.29 & 2.27 & 2009 & 1.14 & 3.20 & 3.20 \\
\hline 2005 & 0.93 & 2.51 & 2.48 & 2010 & 1.09 & 3.34 & 3.34 \\
\hline 2006 & 0.98 & 2.68 & 2.65 & 2011 & 1.07 & 3.33 & 3.33 \\
\hline 2007 & 1.04 & 2.82 & 2.82 & 2012 & 1.03 & 3.37 & 3.37 \\
\hline
\end{tabular}

Notes Column headings are as follows: (1) year, (2) share in the world (\%), (3) share in EU 25 in (\%), (4) share in EU 27 (\%).

port. In 2012, Poland ranked 28th, 26th and 30th, respectively. In relation to EU 27 countries in 2003 Poland ranked 12th, 12th and 16 th, respectively, in order to move to 10th, 8th and 13th position in 2012. For exports per capita, Poland's position in the world in 2003 in the three categories concerned was the following: 72 th, 6 oth and 8 oth. The respective positions for 2012 are 54th, 54th and 68th. In relation to the EU 27, Poland was on 25 th, 22th and 26 th position in 2003 , while in 2012 it ranked 24 th, 23 rd and 25 th, respectively.

Another parameter describing the evolution of Poland's role as an exporter is the so-called Export Performance Index (table 4). This indicator is computed as the ratio of the relation of export to GDP for Poland and 
TABLE 4 Export Performance Index in 2003-2012

\begin{tabular}{|c|c|c|c|c|c|}
\hline (1) & (2) & (3) & (1) & (2) & (3) \\
\hline \multirow[t]{3}{*}{2003} & Poland-E U 25 & 1.096 & 2008 & Poland -E U 25 & 1.074 \\
\hline & Poland-E U 27 & 1.068 & & Poland-E U 27 & 1.074 \\
\hline & Poland-world & 1.418 & & Poland-world & 1.281 \\
\hline \multirow[t]{3}{*}{2004} & Poland-E U 25 & 1.186 & 2009 & Poland-E U 25 & 1.214 \\
\hline & Poland-E U 27 & 1.184 & & Poland-E U 27 & 1.214 \\
\hline & Poland-world & 1.506 & & Poland-world & 1.535 \\
\hline \multirow[t]{3}{*}{2005} & Poland-E U 25 & 1.126 & 2010 & Poland-E U 25 & 1.158 \\
\hline & Poland-E U 27 & 1.125 & & Poland-E U 27 & 1.158 \\
\hline & Poland-world & 1.404 & & Poland-world & 1.481 \\
\hline \multirow[t]{3}{*}{2006} & Poland-E U 25 & 1.141 & 2011 & Poland-E U 25 & 1.141 \\
\hline & Poland-E U 27 & 1.141 & & Poland-E U 27 & 1.141 \\
\hline & Poland-world & 1.422 & & Poland-world & 1.458 \\
\hline \multirow[t]{3}{*}{2007} & Poland-E U 25 & 1.127 & 2012 & Poland-E U 25 & 1.146 \\
\hline & Poland-E U 27 & 1.127 & & Poland-EU 27 & 1.146 \\
\hline & Poland-world & 1.373 & & Poland-world & 1.510 \\
\hline
\end{tabular}

Notes Column headings are as follows: (1) year, (2) relation, (3) export performance index (indicators calculated based on annual values of goods export).

the relation of world export to world GDP. In other words, it measures the relative intensity of a given economy's exports, relating it to the intensity of world export. In 2003-2012 this indicator was at the level between 1.281 (2008) and 1.535 (2009). In general, a slight upward trend can be noted, accordingly. The evolution of this indicator shows an above average (as compared to the world) and gently increasing export intensity of Poland's exports. As regards the changes of the Export Performance Index for the relation Poland-EU 27, it is possible to note its limited growth from 1.068 (2003) to 1.214 (2009).

It is also interesting to analyse the findings for export. As mentioned before, for the period 2003-2012 the export growth indicator for Poland amounted to $306.7 \%$, for the world $-243.1 \%$, and for the EU $27-184.7 \%$. As for the growth of export per capita values, in the investigated period it amounted to $306.0 \%$ for Poland, for the world $-219.0 \%$, and for the EU 27 $-178.6 \%$.

Also favourable for Poland are the figures related to the change of Poland's export share in world export and EU 27 export. It must be stressed 
that the dynamics of Poland's export share changes was significantly higher in relation to the EU 27 than to the world. The share of goods and services export in GDP for Poland was higher throughout the investigated period than for the world, while a comparison with EU 27 indicates similar findings for Poland and the European Union.

Another indicator reflecting the change in Poland's significance in export are the positions occupied in rankings of major exporters. Poland significantly improved its position both in the world and in the European Union. An improvement of Poland's rank in export per capita values also took place, whereby this increase was higher as compared to the world than to the European Union. With regard to the Export Performance Index, Poland's position in the world improved marginally, while the indicator stabilised in relation to $\mathrm{EU} 27$.

\section{CHANGES IN THE GEOGRAPHIC STRUCTURE}

OF POLISH EXPORT

As it was mentioned before, the value of Polish export of goods has been intensively growing. The most recent information concerning foreign exchange of goods for the year 2013 also indicates $7 \%$ growth rate of Polish exports value (Kozłowski 2014). Additionally, according to the latest data, during the first five months of the year 2014 the value of Polish export exceeded the value of its import (Narodowy Bank Polski 2014). This situation is partly explained because of the economic slowdown, which decreased consumption and investment, and therefore reduced Polish demand for imports. However, many economists claim that such situation also results from a lesser dependence of Poland on foreign capital. At the same time, it is often highlighted that the most recent increase in the value of Polish export was recorded not because of Polish currency depreciation or other extraordinary events, but it is rather an outcome of the improving capability of Polish firms to compete successfully in highly demanding foreign markets (Kozłowski 2014). Moreover, it is frequently emphasised that firms located in Poland increasingly embark upon expansion into foreign markets outside of the Eurozone or the European Union, in general. Thanks to those new directions of growth, Polish export has kept growing despite the recent economic slowdown (Kowalczyk 2014).

This part of the paper aims at verifying the assumptions presented above concerning the geographic reorientation of Polish export. The analysis is based on data published by the Central Statistical Office within 


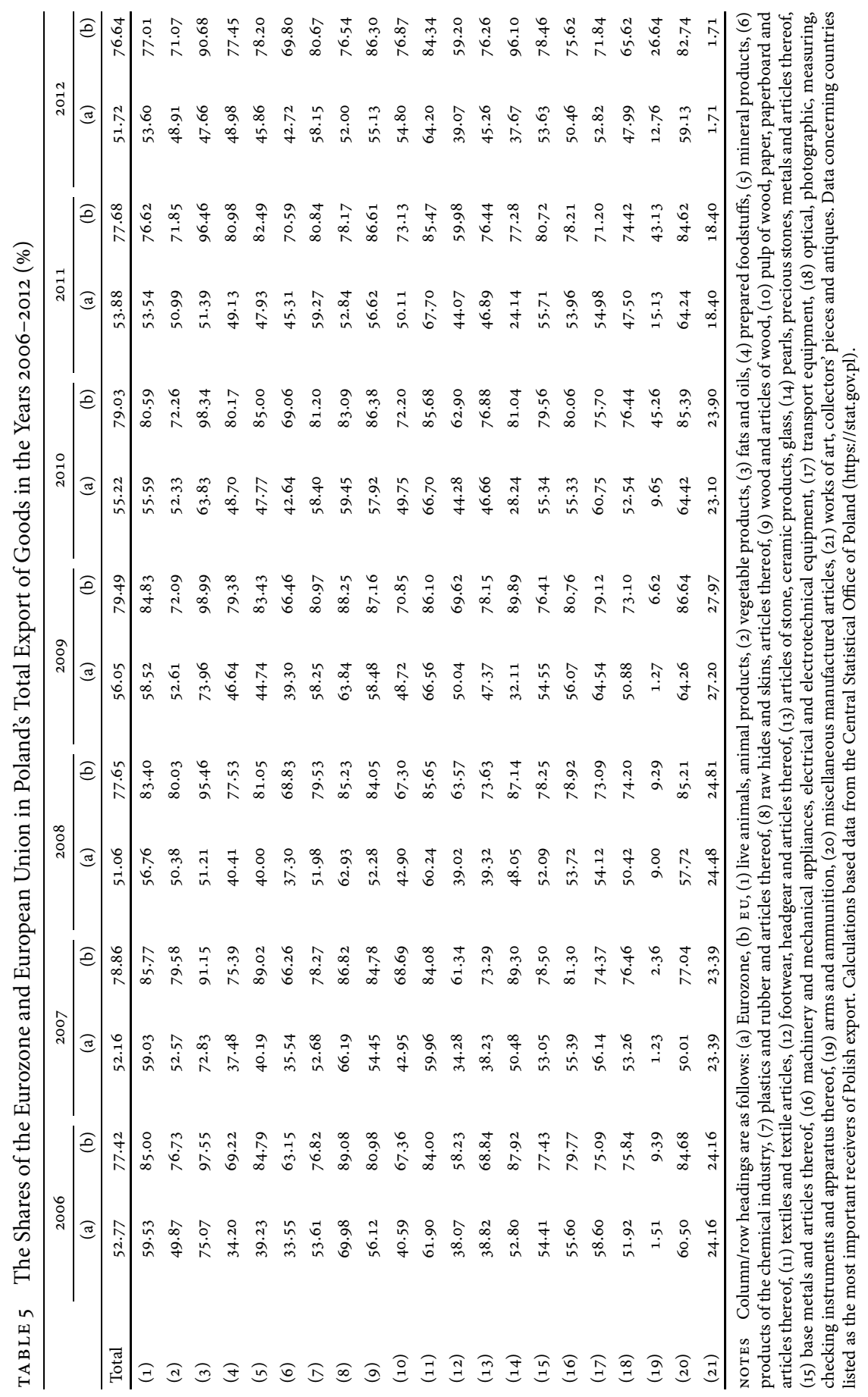




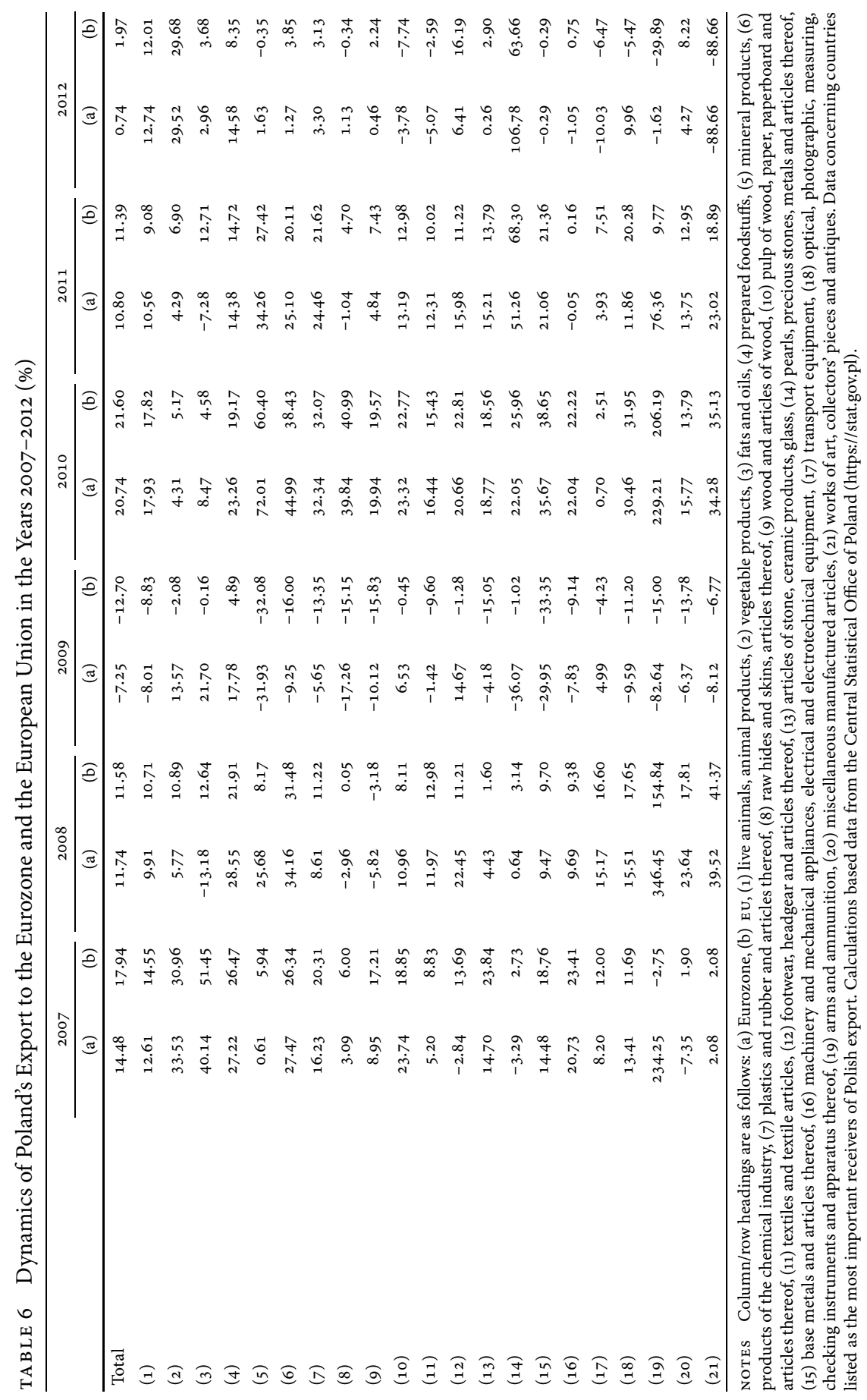


TABLE 7 Shares in Poland's Total Export of Goods and Dynamics of Poland's Export to the Largest Foreign Trade Partners in 2006-2012 (\%)

\begin{tabular}{llrrrrrrr}
\hline Country & & 2006 & 2007 & 2008 & 2009 & 2010 & 2011 & 2012 \\
\hline Germany & (a) & 27.15 & 25.89 & 25.05 & 26.15 & 26.11 & 26.09 & 25.13 \\
& (b) & & 10.48 & 10.44 & -11.81 & 22.35 & 13.48 & 1.10 \\
\hline Italy & (a) & 6.54 & 6.60 & 5.97 & 6.84 & 5.93 & 5.34 & 4.85 \\
& (b) & & 16.92 & 3.25 & -3.18 & 6.24 & 2.14 & -4.69 \\
\hline France & (a) & 6.24 & 6.09 & 6.20 & 6.95 & 6.78 & 6.12 & 5.86 \\
& (b) & & 13.07 & 16.24 & -5.33 & 19.48 & 2.64 & 0.40 \\
\hline Netherlands & (a) & \multirow{2}{*}{3.84} & 3.83 & 4.02 & 4.22 & 4.39 & 4.37 & 4.48 \\
& (b) & & 15.27 & 19.96 & -11.41 & 27.47 & 13.07 & 7.68 \\
\hline United Kingdom & (a) & 5.71 & 5.94 & 5.76 & 6.41 & 6.28 & 6.44 & 6.77 \\
& (b) & & 20.50 & 10.74 & -5.97 & 19.96 & 16.51 & 10.25 \\
\hline Czech Republic & (a) & 5.54 & 5.54 & 5.70 & 5.85 & 5.98 & 6.24 & 6.32 \\
& (b) & & 15.79 & 17.53 & -13.35 & 25.36 & 18.49 & 6.24 \\
\hline Russian Federation & (a) & 4.28 & 4.62 & 5.20 & 3.66 & 4.18 & 4.49 & 5.35 \\
& (b) & & 25.16 & 28.53 & -40.57 & 39.94 & 22.00 & 25.08 \\
\hline
\end{tabular}

NOTES Row headings are a follows: (a) share of export, (b) growth rate (year by year). Calculations based data from the Central Statistical Office of Poland (https://stat.gov.pl).

Yearbooks of Foreign Trade Statistics of Poland in the years 2007-2013. The focus of the analysis is on export activity of Poland during years 2006-2012 according to major countries and activity sections. During the analysed period, the list of Poland's key trade partners consisted of 50 countries, for which data could be obtained.

As indicated in the preceding sections, during the years 2006-2007 and 2010-2011 the values of Polish export grew at a two-digit pace. This growth rate decreased during 2011-2012, however it remained at satisfactory levels. The decrease of the value of Polish export experienced in 2009 can be attributed to the global economic crisis. However, taking into consideration that the value of world export in 2009 diminished by approximately $22 \%$, while the same value for Poland fell down only by about $15 \%$, this can still be regarded as a relatively favourable situation. At the same time, during the analysed period the structure of Polish export according to sectors did not change significantly. Both the biggest decreases and increases of particular section shares, when comparing year 2006 to 2011 and 2006 to $2012^{3}$ amounted to around $1 \%$. The biggest decreases 
took place in the case of base metals and the related goods. At the same time, the biggest increases were related to such sections as products of the chemical industry and prepared foods.

Data presented in table 5 highlights to what extent Polish export is dependent on the European Union and Eurozone members. During the investigated period, around $77 \%$ of Polish export of goods was directed to Poland's biggest foreign trade partners from the European Union, while a bit more than $50 \%$ was absorbed by Eurozone member states. Starting from 2009, the share of the European Union in this regard has been decreasing very slowly. In case of Eurozone, this trend was slightly stronger. Table 6 presents the dynamics of Poland's export to the Eurozone and the European Union during years 2006-2012.

Germany, Italy, France, Netherlands, the United Kingdom, the Czech Republic and Russia were the largest receivers of Polish export during the years 2006-2012. ${ }^{4}$ Table 7 presents data concerning the share of export and dynamics of export for the mentioned countries. The average total share of export to those countries amounted to approximately $59 \%$. However, the majority thereof (about $42 \%$ ) concentrated within the Eurozone. It is worth highlighting that the total share of export to the biggest partners originating from the Eurozone increased between the years 20062009, while afterwards it started decreasing. In this case, the total share of export decreased during years $2009-2012$ from about $44 \%$ to $40 \%$. This decrease is not a result of smaller values of export to the biggest countries, but rather of a slower increase in those values as compared to the total value of Polish export. Nevertheless, fluctuations of foreign currency exchange rates might have also exerted their influence. In the case of Netherlands, the United Kingdom, the Czech Republic and Russian Federation their shares of export have been increasing during the investigated period, which was accomplished by a higher dynamics of export growth. During the investigated period, apart from the already mentioned countries, the only non-European Union member state with a relative high and rising share of Polish export were the Us A. Its share of export rose between the years 2008 and 2012 from the value of $1.45 \%$ up to $1.95 \%$.

Extremely high dynamics of growth during the analysed period characterised values of Polish exports to such countries as: Panama (the average growth rate for the years 2006-2012 amounted to ca. 44\%), Luxembourg (ca. 36\%), Mexico (ca. 35\%), Singapore (ca. 35\%), Indonesia (ca. $31 \%$ ), Brazil (ca. 29\%), India (ca. 26\%) and Japan (ca. 22\%). At the same time, the share of exports directed to those countries in the total exports 
of Poland amounted to $0.97 \%$ in the year 2006 and by the year 2012 it increased to $1.70 \%$. It means that although the speed of growth of exports to those countries is significantly higher than the speed of growth of Polish exports in general, the changes are barely visible in the geographic structure of Polish exports. What is interesting is that the companies operating in a country with relatively short history of market economy and limited experience regarding internationalisation process (Poland), are more focused on competition in the mature and more developed markets (i.e. Germany, France, Italy, Netherlands, the United Kingdom) that face higher rivalry pressure, than in emerging markets (like i.e. Panama, Mexico, Singapore, Indonesia, Brazil and India) with seemingly less fierce competition. This constitutes a paradox that may be partially explained by geographic proximity, the accessibility of mature markets at the beginning of Poland's transition process and global supply chains coordination mechanisms; however, without deeper studies of Polish companies' motivation and decision making process regarding their internationalisation one can only speculate the reasoning behind this phenomenon.

\section{Conclusions and Policy Implications}

To summarise the above considerations, Poland developed faster than the world and faster than EU 27 countries. ${ }^{5}$ The differences in growth rates indicate that there was a larger positive difference in the growth rate of Poland in relation to the EU 27 than in relation to the world. In other words, the process of catching up in terms of economic development was faster in relation to the European Union than to the world. The observed tendencies identified for the period 2003-2012 are characterised by a limited usability for the purpose of prediction of future events. The overlap of a large number of variables concerning particular national economies and specific types of economic policy makes the construction of growth scenarios burdened by a high risk of error. Should similar growth trends sustain in the future (which appears to be confirmed by most predictions), then attention should be paid to further intensification of economic ties with the outside world, since the latter develops faster and it is therefore more promising from the development point of view. The above recommendation is further supported by the so-called Hausner Report in which it was noted that a high concentration of Poland's export to the markets of the European Union is one of the factors causing that from 2009 the export growth rate of Poland was lower than the growth rate of world import (Hausner 2013). It seems, therefore, that the above 
observations constitute a justification for the postulate of increasing the geographic diversification degree of Polish export with shifting emphasis to growth on those markets which will develop at a pace significantly above world average;

The recommendation expressed in the previous point should not be treated in a mechanical, unambiguous and unconditional manner. A withdrawal from efforts to locate more exports in the markets of the European Union would be unwise, particularly in the few industries in which Polish firms score successes resulting from competition based on differentiation, since the market of the European Union creates impulses for further improvement of the quality of goods. Thus, it might be advisable that European markets continue to play the role of a laboratory for further competitiveness enhancement and an outpost for expanding to further countries.

In the years 1990-2012 Poland attained significant economic successes, of which the most important evidence was the attained economic growth rate. The background of this success is related to both internal changes, as well as the opening of the economy for cooperation with foreign partners. Despite the ambiguous economic evaluations of the outcomes of the transformation process, it must be underlined that in comparison to other countries undergoing the same process, Poland performed relatively well. In addition, regardless of frequent opinions that this performance could have been even better, an overall assessment of the process is favourable especially in the foreign economic environment, whereby Poland is frequently regarded as a benchmark for transformation performance.

The changes of the position of the Polish economy in relation to the world and the European Union, presented in the second section of this paper, do convey a generally positive message. However, they cannot obscure the most salient development problems, related particularly to the quality side of the economy. The following weaknesses desire the most acute attention:

- Poland perceived from the perspective of its competitiveness will continue to remain a country of 'peripheral' capitalism, not a country of 'leading technologies' (Blusz and Świeboda 2013, pp. 28-29);

- The Polish economy benefits from efficiency-driven advantages, not from innovation-driven advantages (Blusz and Świeboda 2013, pp. 28-29); 
- Poland's technological advancement is low; it exports cheap labour, shows rather low dialogue capabilities, it constitutes a weakness for its own entrepreneurs, while FDI is weakly related to the domestic production capacity (Hausner and Szymczak 2013).

The mentioned ambiguity of evaluations does not change the fact that the process of closing the development gap between Poland and highly developed market economies has not been accomplished and will arguably last for a period measured in decades. If the declared development aspirations of Poland were to be fulfilled (one of such frequently discussed minimum objectives is the attainment of the average GDP per capita level of the European Union), then Poland can be expected to experience economic growth significantly above the average level of the European Union. Otherwise, the process of catching up would last forever. The intensity of economic ties of Poland with the European Union gives rise to an interesting paradox: in order to catch up with the average GDP per capita level of the European Union (currently, the Polish GDP per capita level amount to about $60 \%$ of the European Union's GDP per capita level), Poland should develop at a higher rate than the average of the European Union. The higher the differences, which will occur in the two rates, the faster Poland, will close the development gap.

However, Poland's fast growth depends on the growth rate of the European Union, inter alia because it is Poland's largest export market. Thus, from this perspective it can be concluded that the ability to reduce the development gap between Poland and the European Union should be derived from areas not included in the said paradox. In other words, by catching up with the European Union, Poland should rely on growth factors, which are not exclusively dependent on the economic situation in the European Union. This recommendation mainly refers but is not limited to export expansion of the Polish economy. The present analysis reflects the increase of countries from beyond the European Union in Poland's internationalisation, although this trend was relatively weak in the investigated period, which may indicate that it remains at a nascent stage.

The above arguments have to find their support in specific policy measures. Currently, in terms of state support for firm internationalisation, the Polish system of incentives for firm internationalisation still remains limited in its scope and dispersed over a range of institutions (Gorynia et al. 2014a). While the Export Credit Insurance Corporation KU KE has ex- 
isted since 1991, its scope of activities has remained relatively limited. The same can be said of the Bank of National Economy (в G К), which had existed in the previous political and economic system, but only introduced export credits and loan guarantees or subsidies and loans for foreign direct investment. In 2000, the Polish Agency for Enterprise Development (PARP) was established to foster SME development, including their overseas promotion and matchmaking. Furthermore, grants for export promotion, or the Polish export promotion portal featuring information on foreign markets and a database of foreign business inquiries and tenders, are offered by the Ministry of Economy. At the same time, Trade and Investment Promotion Sections of Polish Embassies deal with the promotion of Polish business in other countries, information on foreign markets, matchmaking or assistance in organisation of economic missions (Gorynia et al. 2014a). Clearly, the spectrum of instruments dedicated to fostering Polish exports and their geographic diversification is not narrow, however the responsibilities are dispersed between different institutions, which results in overlaps and increased transaction costs for the firms in search of support.

Apart from the deficiencies in the support system, which should be addressed by policy makers, a more fundamental issue is related to creating a supportive business environment, which may be instrumental in fostering international firm competitiveness (Buckley et al. 2010; Globerman and Chen 2010). Poland's Ministry of Economy has already launched such initiatives, including financial support for export projects, the creation of the Network of Investor and Exporter Assistance Centres, or general promotion of the Polish economy abroad. In January 2013, the Polish government adopted the Strategy of Innovativeness and Effectiveness 'Dynamic Poland 2020, whose main objectives are to improve the regulative and financial environment, increase the effectiveness of labour, knowledge or of the usage of natural resources. Thus, an increased diversification of Polish export should be regarded in a broader context of an economic policy framework, which can be supported by a rising number of entrepreneurship-oriented programs co-financed by the European Union.

\section{Notes}

1 The discussion is based on UNCTAD data. In relation to the European Union, data were presented for EU 25 and E 27 countries. The analysis is based only on data for EU 27 countries. Thus, there is an underlying as- 
sumption that the European Union comprised 27 members in the investigated period.

2 All percentage values in the ensuing sections are indices (see tables for details).

3 Such a comparison should exclude analysing industries for which a significant change would be a one-off event.

4 The biggest trade partners were those countries that had an average share of export higher than $4 \%$ during the investigated period.

5 At this juncture attention is confined to issues directly related to the internationalisation of the Polish economy. A broader array of recommendations addressed at Polish public policy were included in Hausner et al. (2013, 22-136). Also compare Gorynia (2006).

\section{References}

Ali, S., J. Nowak, and J. Pöschl 2001. 'A Decade of Transition in Central and Eastern Europe: Trends in Foreign Trade and Foreign Direct Investment.' Paper presented at the the Tenth World Business Congress, Zagreb, 4-8 July.

Blusz, K., and P. Świeboda. 2013. Po naprawie Rzeczypospolitej czas na 'drugą Polskę.' Warszawa: Instytut Idei.

Brenton, P., and D. Gros. 1997. 'Trade Reorientation and Recovery in Transition Economies.' Oxford Review of Economic Policy 13 (3): 65-76.

Buckley, P. J., J. L. Clegg, A. R. Cross, and H. Voss. 2010. 'What Can Emerging Markets Learn from the Outward Direct Investment Policies of Advanced Countries?' In Foreign Direct Investments from Emerging Markets: The Challenges Ahead, edited by K. P. Sauvant and G. McAllister, 243-76. New York: Palgrave Macmillan.

Djankov, S., and C. Freund. 2002. 'Flows in the Former Soviet Union, 19871996.' Journal of Comparative Economics 30 (1): 76-90.

Globerman, S., and V. Z. Chen. 2010. Best Policy Practices for Promoting Inward and Outward Foreign Direct Investment. Ottawa: The Conference Board of Canada.

Gorynia, M. 2002a. 'Internationalization of a Post-Communist Economy - Opportunities and Threats: The Case of Poland.' In Internationalization in Central and Eastern Europe, edited by M. Marinov, 76-104. Aldershot: Ashgate.

- ' Internationalisation of Economy versus Economic Policy under Integration and Globalisation.' Poznań University of Economics Review 2 (2): 5-19.

- 2005. Strategie firm polskich wobec ekspansji inwestorów zagranicznych. Warszawa: PWE. 
- 2006. 'Polska polityka gospodarcza a internacjonalizacja i globalizacja.' Ruch Prawniczy, Ekonomiczny i Socjologiczny, no. 2: 129-46.

Gorynia, M., and T. Kowalski. 2008. 'Globalne i krajowe uwarunkowania funkcjonowania polskich przedsiębiorstw.' Ekonomista, no. 1: 51-76.

Gorynia, M., J. Nowak, P. Trąpczyński, and R. Wolniak. 2013. 'Internationalization of Polish Firms via Foreign Direct Investment: A MultipleCase Study Approach.' In Successes and Challenges of Emerging Economy Multinationals, edited by M. A. Marinov and S. T. Marinova, 184216. New York: Palgrave Macmillan.

- 2014a. 'Should Governments Support Outward FDI? The Case of Poland. In Institutional Impacts on Firm Internationalization, edited by S. Marinova, 120-45. London and New York: Palgrave Macmillan.

- 2014b. 'The Internationalization of Polish Firms: Evidence from a Qualitative Study of F D I Behavior.' In Internationalization of Firms from Economies-in-Transition: The Effects of Politico-Economic Paradigm Shift, edited by E. Turkina and M. T. T. Thai, 39-66. Cheltenham: Elgar.

Gorynia, M., J. Nowak, and R. Wolniak. 2007. 'Poland and Its Investment Development Path.' Eastern European Economics 45 (2): 52-74.

Gorynia, M., and R. Wolniak. 2002. 'The Participation of Transitional Economy in Globalisation: The Case of Poland.' Journal of Euro-Asian Management 6 (2): 57-75.

Hausner, J., ed. 2013. Konkurencyjna Polska: Jak awansować w światowej lidze gospodarczej? Kraków: Fundacja Gospodarki i Administracji Publicznej.

Hausner, J., and R. Szymczak. 2013. 'Jak awansować w światowej lidze?' Rzeczpospolita, 20 June.

Hoekman, B., and S. Djankov. 1999. 'Intra-Industry Trade, Foreign Direct Investment, and the Reorientation of Eastern European Exports.' Policy Research Working Paper Series 1652, The World Bank, Washington, DC.

Kamiński, B. 1996. 'Factors Affecting Trade Reorientation of the Newly Independent States.' In Economic Transition in Russia and the New States of Eurasia, edited by B. Kamiński, 384-416. Armonk, NY: Sharpe.

Kamiński, B., Z. K. Wang, and L. A. Winters. 1996. 'Trade Performance: Export Reorientation in the Transition.' Economic Policy 23 (10): 42342.

Kandogan, Y. 2006. 'The Reorientation of Transition Countries' Exports: Changes in Quantity, Quality and Variety.' Intereconomics: Review of European Economic Policy 41 (4): 216-29.

Kowalczyk, J. 2014. 'Polscy eksporterzy zdobywają dziki zachód.' Puls Biznesu, 22 January. 
Kozłowski, Ł. 2014. 'Eksport stał się filarem polskiej gospodarki'. Spedycje.pl, 12 February.

Lendesmann, M., and I. Szekely. 1995. Restructuring and Trade Reorientation in Eastern Europe. Cambridge: Cambridge.

Narodowy Bank Polski. 2014. Bilans płatniczy Polski w maju 2014. Warsaw: Narodowy Bank Polski.

Siemiończyk, G. 2014. 'Polskę czeka reorientacja eksportu.' Rzeczpospolita, 18 March.

Szalavetz, A., and M. Lucke. 1999. 'Export Reorientation and Transfer of Know-How and Technology - The Case of Hungarian Manufactured Exports.' In Innovation and Technological Change in Eastern Europe: Pathways to Industrial Recovery, edited by M. Fritsch, and H. Brezinski, 123-41. Cheltenham: Elgar.

Vanyai, J., and E. Viszt. 1992. 'Foreign-Trade Reorientation and the RubbleBased Exports.' Russian and East European Finance and Trade 28 (3): 76-92.

Winiecki, J. 2000a. 'Successes of Trade Reorientation and Expansion in Post-Communist Transition: An Eterprise Level Approach.' Banca Nazionale del Lavoro Quarterly Review 53 (213): 187-223.

, ed. 20oob. Transition Economies and Foreign Trade. London and New York: Routledge. 